\title{
Effects of Active Learning for Curriculum Management: with Focus on the "Courses of Study" of Japan
}

\author{
Hiroki Yoshida
}

\begin{abstract}
On November 22th, 2014, the Education Minister of Japan proposed to promote "active learning" in elementary and secondary education, and to promote effective curriculum management at each school by aligning the process of planning, implementing, assessing, and improving curricula. This study purposed to promote pre-service teachers' understanding and skills of curriculum management by the implementation of active learning. Participants were 56 first-year university students who were taking pre-service teacher education courses for elementary and secondary education. All of the participants were participating in a curriculum studies class. Participants first studied the aims, structure and contents of the "Courses of Study" in Japan, and they learned how to develop, analyze, manage, evaluate, and revise a school curriculum. Then, they worked in a group of six using the jigsaw method to analyze the "Courses of Study." Results of the study show that students who learned actively in a small group significantly increased their understanding $(t(55)=3.03, p<.00)$ and skills $(t(55)=6.51, p$ $<.00)$ in curriculum management week by week. Results suggest that if students learn actively and cooperatively, they could understand what is important in managing a curriculum.
\end{abstract}

Index Terms-Active learning, Jigsaw method, curriculum management, "courses of study".

\section{INTRODUCTION}

Knowledge-based society has brought about a paradigm shift in teaching and learning [1]. In order to cope with the structural change of the society, school systems are required to recognize the significance of learning objectives such as social competence, critical thinking, knowledge sharing, and cooperation techniques [2]. DeSeco [3] defined three categories of key competencies that are essential for children in the knowledge-based society, namely, 1) using tools interactively, 2) interacting in socially heterogeneous groups, and 3) acting autonomously. In Japan, the Ministry of Education, Culture, Sports, Science and Technology [4] noted in 'Improving 'Courses of Study' of Kindergartens, Elementary Schools, Lower and Upper Secondary Schools, and Schools for Special Needs Education: Report" that 1) basic and fundamental knowledge and skills, and 2) thinking skills, decision-making skills, expression skills are required to survive the society, and 3) coexistence and cooperation is necessary for the sustainable growth of the society. Therefore, learning methods that require active and promotive interaction among the learners such as active learning are being implemented in schools at all levels: from elementary to

Manuscript received October 10, 2015; revised February 29, 2016. This work was supported by JSPS KAKENHI Grant Number 25350360.

Hiroki Yoshida is with Tokoha University, Shizuoka, Japan (e-mail: h-yoshida@av-lab.org). higher education.

Active learning is defined by Bonwell \& Eison [5] as an instructional method "that involves students in doing things and thinking about the things they are doing." The core elements of active learning are "student activity and engagement in the learning process" [6]. Previous studies note that active learning promotes students' academic achievement [7]-[9], engagement [10]-[12], motivation [13]-[15], self-efficacy [16]-[18], and attitude [19], [20].

\section{A. "Courses of Study" as a National Education Guideline for Elementary and Secondary Education in Japan}

Elementary and secondary schools in Japan develop school curricula and classroom lessons based on the national education guideline "Courses of Study." It is specified in the Regulations for the Enforcement of the School Education Act, which were issued in 1947 that curricula in elementary and secondary schools in Japan have to meet standards established by the Minister of Education in its "Courses of Study."

The first "Courses of Study (Tentative Draft)" was announced in 1947 and the respective "Courses of Study" for each subject: Japanese language, social studies, mathematics, science, music, physical education, arts and crafts, home economics, and free study followed it. Social Studies formed the core of the "Courses of Study," with the purpose of teaching students about community life, and promoting their social skills and attitude to adapt to their society [21]. Since then, the "Courses of Study" has been revised seven times.

In 1996, the sixth "Courses of Study" was revised following the recommendations of the Central Council for Education. The Central Council for Education reported in "The Model for Japanese Education in the Perspective of the 21 st Century" to develop students' "zest for living" through autonomous learning. [22], [23]" "Zest of living" means well-balanced competencies of 1) solid academic capabilities, 2) well-rounded character, and 3) healthy body in order to live in the rapid changing society [24]. Fig. 1 depicts the concept of "zest of living."

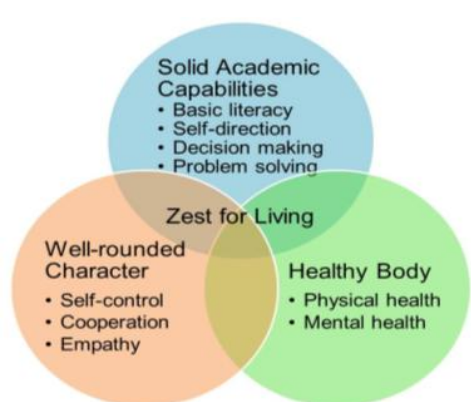

Fig. 1. Structure of "zest for living" (source: MEXT, 2010, translated by author). 
In 2006, the Central Council for Education issued that the descriptions of learning and evaluating methods for realizing curriculum guidelines to foster "zest of life" is not sufficient. Following the Council's report, the Basic Act on Education which sets national aims and goals of education in Japan was revised in December 2006 for the first time in approximately 60 years [25]-[27].

Along with the revision of the Basic Act on Education, the School Education Act was amended in 2006 requiring elementary schools to develop pupils' basic literacy, to promote their thinking skills, decision-making skills, expression skills, and to promote positive attitude toward learning. In reaction to the amendment of the School Education Act, the "Courses of Study" was revised in 2008 with the emphasis to cultivate students" "zest for life," by balancing attainment of basic knowledge and skills with thinking skills, decision-making skills, and expression skills, and to nurture rich and wholesome heart and body [28].

\section{B. Active Learning in Japan}

The Prime Minister of Japan and His Cabinet announced the New Growth Strategy in 2010, and suggested schools to design and organize cooperative and/or collaborative learning classes in which students teach each other and learn from each other [29]. In 2011, the Ministry of Education, Culture, Sports, Science and Technology-Japan announced the Vision of ICT in Education and recommended schools to promote "individualized learning responding to each child's abilities and personality, and collaborative learning where children can teach and learn among themselves, in addition to conventional mass learning by guidance all at once [30]".

Japanese Education Minister Hakubun Shimomura proposed in the "Curriculum Standards for Elementary and Secondary Education: Inquiry" to revise the "Courses of Study" on November 22th, 2014 [31]. Education Minister tasked the Central Council for Education to revise the "Courses of Study" by 2016, and to implement the revised "Courses of Study" to school curricula from April 1st, 2020. Minister insisted that teachers have to enhance "students' motivation to study actively, attitude to respect diversity, ability of leadership, teamwork, and communication to work cooperatively with others." Minister emphasized that the government and schools must review and revise not only educational aims and contents but also educational methods and environments in order to enhance such qualities or abilities. Particularly, Education Minister suggested promoting "active Learning" which is a learning method in which students learning actively and cooperatively in order to find and solve problems in the society and daily life.

\section{Curriculum Management in Japan}

The concept "curriculum management" was first presented in Japan by the Central Council for Education in "Tactics to Improve Curricula and Instruction for Elementary and Secondary Education: Report [32].” The Council suggested principals and teachers to further their understanding of the "Courses of study" and their school curricula, and to promote their understanding and skills in curriculum development and curriculum management.

In 2008, the Central Council for Education illustrated the importance to popularize the concept of curriculum management in 'Improving 'Courses of Study' of Kindergartens, Elementary Schools, Lower and Upper Secondary Schools, and Schools for Special Needs Education: Report [4]." The Council required curriculum administrators to 1) provide teachers practical examples of what the "Courses of Study" puts major emphasis on, 2) improve the educational environment so that teachers have enough time to communicate well with students, 3) develop and implement reality-based school curricula, 4) properly assess educational outcomes, and 5) improve educational activities based on the basis of school assessment. That is to say, curriculum administrators should manage curricula using a Plan-Do-Check-Act (PDCA) cycle.

Furthermore, in the "Curriculum Standards for Elementary and Secondary Education: Inquiry," Education Minister Shimomura proposed to the Central Council for Education to promote effective curriculum management at each school by aligning the process of planning, implementing, assessing, and improving curricula along with the revision of the current "Courses of Study [31]."

Under these circumstances, it is necessary to enhance pre-service elementary and secondary teachers' understanding and skills in curriculum management and active learning. Therefore, this study purposed to identify the effects of active learning on pre-service teachers' understanding and skills of curriculum management.

\section{PURPOSE}

The purpose of the study is to investigate the effects of active learning on pre-service teachers' understanding and skills of curriculum management, and their attitude toward active learning.

The research questions to be addressed in this study are: 1) What effects do active learning have on pre-service teachers' understanding of curriculum management? 2) What effects do active learning have on pre-service teachers' curriculum management skills? 3) What effects do active learning have on pre-service teachers' attitude toward active learning?

\section{METHOD}

The study was conducted from April 27th to May 18th, 2015 with the purpose of identifying the effects of active learning on pre-service teachers' understanding and skills of curriculum management.

\section{A. Participants}

Participants were 56 first-year university students who were taking pre-service teacher education courses for elementary and secondary education. All of the participants were participating in a curriculum studies class.

\section{B. Instruments}

Six assessment instruments were used to assess participants' achievement and performance. Mini-quizzes were used to assess participants understanding of curriculum management and a worksheet was used to evaluate their performance of curriculum management. Fig. 2 shows the 
outline of the worksheet that was used in this study.

\begin{tabular}{|c|c|c|c|}
\hline Subject & $\begin{array}{l}\text { Description that typifies the Xth } \\
\text { version of the Course of Study }\end{array}$ & \begin{tabular}{|c|}
$\begin{array}{c}\text { Difference and similarity } \\
\text { between the two versions of the } \\
\text { Course of Study }\end{array}$ \\
\end{tabular} & $\begin{array}{l}\text { Description that typifies the Yth } \\
\text { version of the Course of Study }\end{array}$ \\
\hline Japanese & & & \\
\hline $\begin{array}{l}\text { Social } \\
\text { Studies }\end{array}$ & & & \\
\hline Mathemati & & & \\
\hline Science & & & \\
\hline Music & & & \\
\hline $\begin{array}{l}\text { Physical } \\
\text { Education }\end{array}$ & & & \\
\hline
\end{tabular}

Fig. 2. Outline of the worksheet used in this study (translated by author).

A task-specific coaching rubric with three criteria and four standards/rating levels: S (Exceeds expectations), A (Meets expectations), B (Needs Improvement), C (Inadequate) was used to assess participants' performance, and a ten-item quiz was used to assess participants understanding on curriculum management. As the rubric was a coaching rubric, it was provided to the participants in advance of the active learning activity so as to enhance participants' skills and understanding of curriculum management. Fig. 3 shows the outline of the rubric used in this study.

第5回授業課題(平成元年、平成 10 年指等要領の分析)評価基準表

\begin{tabular}{|c|c|c|c|c|c|}
\hline 評価観点 & 評価規準 & 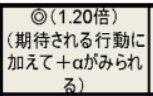 & $\begin{array}{c}\mathrm{O} \text { (1.00倍) } \\
\begin{array}{c}\text { (期待されるる行動が } \\
\text { みられる }\end{array} \\
\end{array}$ & 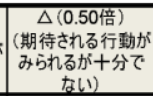 & 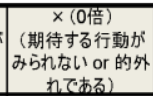 \\
\hline $\begin{array}{l}\text { 奉成元年指 } \\
\text { 道要領(試 } \\
\text { 案)の特徽の) } \\
\text { 抽出 }\end{array}$ & \begin{tabular}{|l} 
「個性化·多様化」 \\
を表す記述を报き \\
出している。
\end{tabular} & 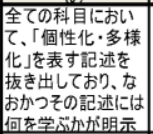 & \begin{tabular}{|l|} 
全ての科目におい \\
て、「個性化・多様 \\
化」を表す記速を \\
抜き出している。 \\
\\
\end{tabular} & $\begin{array}{l}\text { 一部の科目におい } \\
\text { て、「個性化・多様 } \\
\text { 化」を表す記述を } \\
\text { 拢き出していない。 }\end{array}$ & $\begin{array}{l}\text { 多くの科目におい } \\
\text { て、「個性化・多様 } \\
\text { 化」を表す記述を } \\
\text { 报き出していない。 }\end{array}$ \\
\hline $\begin{array}{l}\text { 平成10年指 } \\
\text { 導要領の分 } \\
\text { 析 }\end{array}$ & 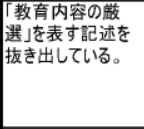 & 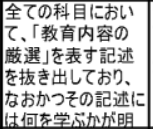 & $\begin{array}{l}\text { 全ての科目におい } \\
\text { て、「教育内容の } \\
\text { 敩選」を表す記述 } \\
\text { を报き出している。 }\end{array}$ & \begin{tabular}{|l} 
一部の科目におい \\
て、「教内内容の \\
絾選」を表す記述 \\
を报き出していな \\
い。
\end{tabular} & $\begin{array}{l}\text { 多〈の科目におい } \\
\text { て、「教育内容の } \\
\text { 歲選」を表す記述 } \\
\text { を拢き出していな } \\
\text { い。 }\end{array}$ \\
\hline $\begin{array}{l}\text { 指導要領の } \\
\text { 特徽の違い } \\
\text { の分析 }\end{array}$ & \begin{tabular}{|l} 
平成元年指導要 \\
領と平成10年指 \\
道要領の違いが明 \\
確に記述されてい \\
る。
\end{tabular} & 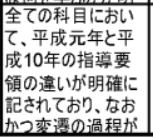 & \begin{tabular}{|l|} 
全ての科目におい \\
て、平成元年と平 \\
成10年の指導要 \\
領の違いが明確に \\
記されている。
\end{tabular} & $\begin{array}{l}\text { 一部の科目におい } \\
\text { て、平成元年と平 } \\
\text { 成10年年の指導 } \\
\text { 要領の違いが明確 } \\
\text { に記されていない。 }\end{array}$ & 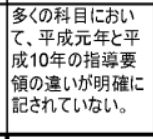 \\
\hline
\end{tabular}

Fig. 3. Outline of the coaching rubric used in this study.

Set out below are the criteria and standards of the rubric.

\section{1) Item: Worksheet}

- Criteria one: Extraction of information that typifies the Xth version of the "Courses of Study"
1) S: Has extracted information that typifies the $X$ th version of the "Courses of Study" in all of the subjects, and the description is specific.

2) A: Has extracted information that typifies the $X$ th version of the "Courses of Study" in all of the subjects.

3) B: Has not extracted information that typifies the Xth version of the "Courses of Study" in one or two subjects.

4) C: Has not extracted information that typifies the Xth version of the "Courses of Study" in more than three subjects.

- Criteria two: Extraction of information that typifies the Yth version of the "Courses of Study"

1) S: Has extracted information that typifies the $Y$ th version of the "Courses of Study" in all of the subjects, and the description is specific.

2) A: Has extracted information that typifies the Yth version of the "Courses of Study" in all of the subjects.

3) B: Has not extracted information that typifies the Yth version of the "Courses of Study" in one or two subjects.

4) C: Has not extracted information that typifies the Yth version of the "Courses of Study" in more than three subjects.

- Criteria three: Clarification of the differences between the two versions of the "Courses of Study"

1) S: Has clarified the differences between the two versions of the "Courses of Study" in all of the subjects along with some specific rationale.

2) A: Has clarified the differences between the two versions of the "Courses of Study" in all of the subjects.

3) B: Has not clarified the differences between the two versions of the "Courses of Study" in one or two subjects.

4) C: Has clarified the differences between the two versions of the "Courses of Study" in more than three subjects.

A five item questionnaire on a 4-point Likert scale ranging from 1 (strongly disagree) to 4 (strongly agree) was used for peer evaluation of participants' performance in active learning. The five questions were:

1) Has extracted information that typifies the $X$ th version of the "Courses of Study."

2) Has extracted information that typifies the Yth version of the "Courses of Study."

3) Has clarified the differences between the two versions of the "Courses of Study."

4) Has pointed out features of the "Courses of Studies" "which I did not notice.

5) The presentation was well organized.

A seven item questionnaire on a 4-point Likert scale ranging from 1 (strongly disagree) to 4 (strongly agree) was used to assess their attitude toward active learning. The seven questions were:

1) Active learning is useful for learning how to learn.

2) Learning actively in a group is delightful.

3) I can focus on studying when I learn actively.

4) I can deepen my understanding of the topic by learning cooperatively.

5) I can develop confidence by learning cooperatively.

6) I can understand the importance of the group members by learning cooperatively.

7) I can understand the individual learning by learning cooperatively. 


\section{Procedure}

All of the participants attended a curriculum studies class for fifteen weeks. Participants studied the aims, structure and contents of the "Courses of Study" in Japan, and they learned how to develop, analyze, manage, evaluate, and revise a school curriculum. Participants analyzed the "Courses of Study" in the former six weeks, and then, they developed a school curriculum in the latter nine weeks.

During the curriculum analysis session, participants worked cooperatively in a group of six. The "Courses of Study" for elementary education is composed of nine subjects: Japanese language, social studies, mathematics, science, music, physical education, arts and crafts, life environmental studies, and home economics so each member of the group was assigned to a different subject. Jigsaw method was used as a method of active learning to facilitate participants' cooperation. Each lesson was structured as follows:

(Before class: Analysis of a subject curriculum)

1) Mini-quizzes: 5 min.

2) Comments and advices on the active learning activity of the previous week: $5 \mathrm{~min}$.

3) Instruction on the active learning activity: $5 \mathrm{~min}$.

4) Discussion in expert group: $20 \mathrm{~min}$.

5) Discussion in home group: $20 \mathrm{~min}$.

6) Report on group discussion: $5 \mathrm{~min}$.

7) Lecture on curriculum management: $25 \mathrm{~min}$.

8) Notice on next weeks' lesson: 5 min.

Total: $90 \mathrm{~min}$.

The jigsaw method was developed by Elliot Aronson as a cooperative learning technique [33]. In the jigsaw leaning environment, members of each cooperative group are assigned materials or tasks and are required to become "experts" on the sub-topics of the study. After becoming "experts" on the different aspects of the topic, members from different groups form a jigsaw group to discuss the main topic. The jigsaw group's goal is that all members of the group master all aspects of the main topic [34]-[36]." The jigsaw method was applied in this study for three major reasons: 1) to enable students share roles and responsibilities by learning cooperatively, 2) to enable students widen their ideas by sharing different ideas, and 3) to enable students deepen their ideas by teaching and/or reporting their ideas to other group members.

On the first, week, participants were provided guidance on the class, were instructed what jigsaw method is, and were informed the basic competences that would be achieved in the class. On the second week, students were lectured on the basic concepts, procedure, skills of curriculum management, and they experienced jigsaw learning on trial.

From the third to sixth week, participants worked in jigsaw active learning groups. Firstly, participants were assigned to expert groups according to the subject curriculum they were to analyze. Participants analyzed six subject curricula: Japanese language, social studies, mathematics, science, music, and physical education. Each student exchanged their findings of the subject curricula they studied. Then, they discussed and summarized the features of the subject curricula. Secondly, participants worked in home groups (see Fig. 4). Participants reported their findings in the expert groups. Next, each jigsaw group formed conclusions on the features of the "Courses of Studies" they analyzed. Thirdly, participants reported the summary of their findings and conclusion to other groups.

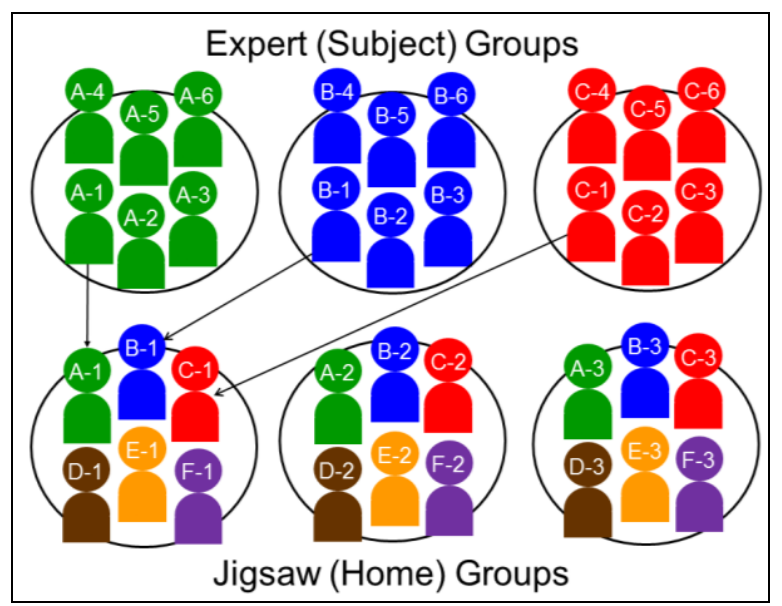

Fig. 4. Distribution of participants into expert (subject) groups and jigsaw (home) groups.

The process of jigsaw active learning was based on the following learning cycle: presentation, reflection, reconstruction, and organization (see Fig. 5).

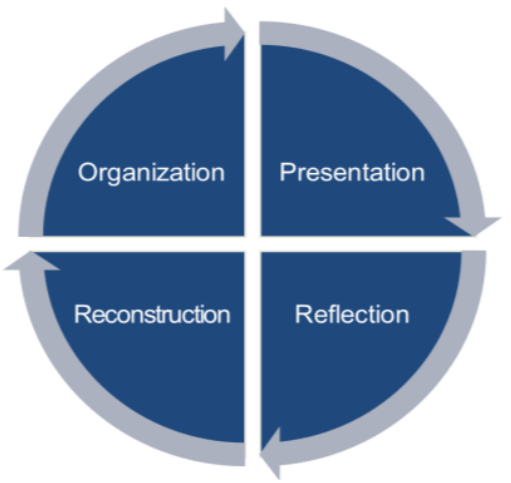

Fig. 5. Learning cycle of the jigsaw active learning

After the active learning phase, participants got lectures about the features of the next two versions of the "Courses of Studies," and they were instructed what they are going to do next week.

\section{RESUlTS}

All of the 56 participants completed the learning task, mini-quizzes, and questionnaire. This means that the response rate was 100.00 percent. Hereinafter, results of the 56 answers will be introduced.

\section{A. Participants' Profile}

Table I shows the breakdown of participants by gender and teacher education courses they enrolled.

\section{B. Effects of Active Learning on Understanding of Curriculum Management}

Participants' understanding of curriculum management was evaluated by a ten-item quiz on a ten-point scale. Table II shows the week-by-week changes in participants' scores.

Effects of active learning were examined by comparing participants' scores on the third and sixth week. For 
evaluation of the differences, Student's one-tailed $t$-test was used.

TABLE I: PARTICIPANTS' PROFILE

\begin{tabular}{|c|c|c|c|}
\hline \multicolumn{2}{|r|}{ Profile of participants } & $F$ & $\%$ \\
\hline \multirow{3}{*}{ Gender } & Male & 30 & $53.57 \%$ \\
\hline & Female & 26 & $46.43 \%$ \\
\hline & Total & 56 & $100.00 \%$ \\
\hline \multirow{5}{*}{$\begin{array}{l}\text { Teacher } \\
\text { education } \\
\text { courses } \\
\text { enrolled } \\
\text { (multiple } \\
\text { answers) }\end{array}$} & Elementary education & 56 & $100.00 \%$ \\
\hline & $\begin{array}{l}\text { Secondary education } \\
\text { (Physical education) }\end{array}$ & 16 & $28.57 \%$ \\
\hline & Lifelong Learning & 10 & $17.86 \%$ \\
\hline & Educational Psychology & 15 & $26.79 \%$ \\
\hline & Clinical Psychology & 15 & $26.79 \%$ \\
\hline
\end{tabular}

TABLE II: PARTICIPANTS’ UNDERSTANDING OF CURRICULUM DEVELOPMENT

\begin{tabular}{l|r|r|r|r}
\hline \hline & week 3 & week 4 & week 5 & week 6 \\
\hline $\begin{array}{l}\text { Understanding of Curriculum } \\
\text { Management }\end{array}$ & 6.94 & 7.55 & 7.83 & 7.90 \\
\hline \hline
\end{tabular}

Table III shows the effects of active learning on participants' understanding of curriculum management. Results indicate that learners' understanding of curriculum management significantly increased by the implementation of active learning $(t(55)=3.03, p<.00)$.

TABLE III: EFFECTS OF ACTIVE LEARNING ON PARTICIPANTS' UNDERSTANDING OF CURRICULUM DEVELOPMENT

\begin{tabular}{l|r|r|r|r|r}
\hline \hline & $\begin{array}{c}\text { week 3, } \\
\text { mean (SD) }\end{array}$ & $\begin{array}{c}\text { week 6, mean } \\
\text { (SD) }\end{array}$ & $d f$ & $t$ & $P$ \\
\hline $\begin{array}{l}\text { Understanding of } \\
\text { Curriculum } \\
\text { Management }\end{array}$ & 6.94 & 7.90 & 55 & 3.03 & $<.00$ \\
\hline \hline
\end{tabular}

\section{Effects of Active Learning on Curriculum Management Skills}

Participants' performances of curriculum management were evaluated by a three criteria task-specific rubric on a 5 point scale. Table IV shows the week-by-week changes in participants' scores.

TABLE IV: PARTICIPANTS' CURRICULUM MANAGEMENT SKILLS

\begin{tabular}{l|r|r|r|r}
\hline \hline & week 3 & week 4 & week 5 & week 6 \\
\hline Curriculum Management Skills & 3.83 & 4.10 & 4.03 & 4.38 \\
\hline \hline
\end{tabular}

Effects of active learning were examined by comparing participants' scores of the learning task on the third and sixth week. For evaluation of the differences, Student's one-tailed $t$-test was used.

TABLE V: EFFECTS OF ACTIVE LEARNING ON THE PROMOTION OF PARTICIPANTS' CURRICULUM MANAGEMENT SKILLS

\begin{tabular}{c|c|c|c|c|c}
\hline \hline & $\begin{array}{c}\text { week 3, } \\
\text { mean (SD) }\end{array}$ & $\begin{array}{c}\text { week 6, mean } \\
\text { (SD) }\end{array}$ & $d f$ & $t$ & $P$ \\
\hline $\begin{array}{c}\text { Curriculum } \\
\text { Management } \\
\text { Skills }\end{array}$ & 3.83 & 4.38 & 55 & 6.51 & $<.00$ \\
$(0.56)$ & $(0.32)$ & 5 ARTICIPANTS' CURRICULUM MANAGEMENT SKILLS \\
\hline \hline
\end{tabular}

Table V shows the effects of active learning on participants' curriculum management skills. Results indicate that learners' curriculum management skills significantly increased by the implementation of active learning $(t(55)=$ $6.51, p<.00)$.

Fig. 6 is an example of a worksheet that was developed by the participants.

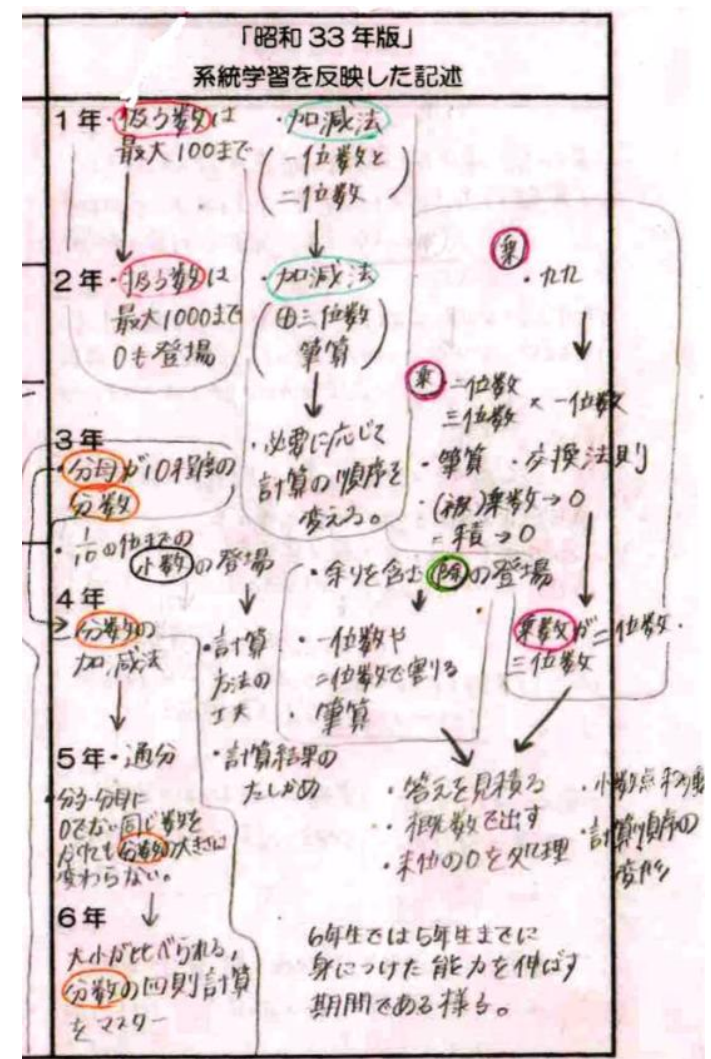

Fig. 6. Example of a worksheet developed by the participants.

\section{Peer Evaluation of Participants' Performance in Active Learning}

Participants did peer evaluation on their performance in active learning by a five item questionnaire on a four-point Likert scale. Table VI shows results of peer evaluation of participants' performance in active learning. The mean was calculated by giving each of the Likert scale points a number value, where strongly disagree $=1$, disagree $=2$, agree $=3$, and strongly agree $=4$.

TABLE VI: PEer EVAluAtion OF PARTICIPANTS' PERFORMANCE IN ACTIVE

\begin{tabular}{|c|c|c|c|c|}
\hline & week 3 & week 4 & week 5 & week 6 \\
\hline $\begin{array}{l}\text { Has extracted information that } \\
\text { 1. typifies the Xth version of the } \\
\text { "Courses of Study." }\end{array}$ & 3.25 & 3.44 & 3.51 & 3.71 \\
\hline $\begin{array}{l}\text { Has extracted information that } \\
\text { 2. typifies the Yth version of the } \\
\text { "Courses of Study." }\end{array}$ & 3.25 & 3.39 & 3.46 & 3.64 \\
\hline $\begin{array}{l}\text { Has clarified the differences } \\
\text { 3. between the two versions of the } \\
\text { "Courses of Study." }\end{array}$ & 3.25 & 3.26 & 3.51 & 3.52 \\
\hline $\begin{array}{l}\text { Has pointed out features of the } \\
\text { 4. "Courses of Studies" which I did } \\
\text { not notice. }\end{array}$ & 3.20 & 3.06 & 3.25 & 3.15 \\
\hline $\begin{array}{l}\text { The presentation was well } \\
\text { organized. }\end{array}$ & 3.18 & 3.04 & 3.37 & 3.44 \\
\hline
\end{tabular}

Effects of active learning on peer evaluation of 
participants' performance were examined by comparing participants' peer evaluation scores on the third and sixth week. For evaluation of the differences, Student's one-tailed $t$-test was used.

Table VII shows the difference of participants' peer evaluation scores of participants' performance in active learning. Results show that learners' performance in analyzing a curriculum $(t(42)=3.56, p<.00 ; t(42)=2.89, p$ $<.00)$, and their skills in organizing a presentation $(t(42)=$ $2.12, p<.05)$ have significantly increased by the use of active learning.

TABLE VII: STATISTICAL ANALYSIS OF PEER EVALUATION OF PARTICIPANTS' PERFORMANCE IN ACTIVE LEARNING

\begin{tabular}{|c|c|c|c|c|c|}
\hline & $\begin{array}{l}\text { week 3, } \\
\text { mean } \\
(\mathrm{SD})\end{array}$ & $\begin{array}{l}\text { week 6, } \\
\text { mean } \\
(\mathrm{SD})\end{array}$ & $d f$ & $t$ & $P$ \\
\hline $\begin{array}{l}\text { Has extracted information } \\
\text { that typifies the Xth version } \\
\text { of the "Courses of Study." }\end{array}$ & 3.25 & 3.71 & 42 & 3.56 & $<.00$ \\
\hline $\begin{array}{l}\text { Has extracted information } \\
\text { that typifies the Yth version } \\
\text { of the "Courses of Study." }\end{array}$ & 3.25 & $\begin{array}{r}3.64 \\
(0.60)\end{array}$ & 42 & 2.89 & $<.00$ \\
\hline $\begin{array}{l}\text { Has clarified the differences } \\
\text { between the two versions of } \\
\text { the "Courses of Study." }\end{array}$ & 3.25 & 3.52 & 42 & 1.57 & 0.06 \\
\hline $\begin{array}{l}\text { Has pointed out features of } \\
\text { the "Courses of Studies" } \\
\text { which I did not notice. }\end{array}$ & 3.2 & $\begin{array}{r}3.15 \\
(0.83)\end{array}$ & 42 & 0.20 & 0.42 \\
\hline $\begin{array}{l}\text { The presentation was well } \\
\text { organized. }\end{array}$ & $\begin{array}{r}3.18 \\
(0.66)\end{array}$ & $\begin{array}{r}3.44 \\
(0.60)\end{array}$ & 42 & 2.12 & $<.05$ \\
\hline
\end{tabular}

\section{E. Participants' Attitude toward Active Learning}

TABLE VIII: PARTICIPANTS’ ATTITUDE TOWARD ACTIVE LEARNING

\begin{tabular}{l|c}
\hline \multicolumn{1}{c|}{ Item } & Mean \\
\hline 1. Active learning is useful for learning how to learn. & 3.43 \\
\hline 2. Learning actively in a group is delightful. & 3.43 \\
\hline 3. I can focus on studying when I learn actively. & 3.30 \\
\hline 4. I can deepen my understanding of the topic by learning \\
cooperatively. & 3.50 \\
\hline 5. I can develop confidence by learning cooperatively. & 2.95 \\
\hline $\begin{array}{l}\text { I can understand the importance of the group members by } \\
\text { learning cooperatively. }\end{array}$ & 3.50 \\
\hline $\begin{array}{l}\text { I can understand the importance of individual learning by } \\
\text { learning cooperatively. }\end{array}$ & 3.59 \\
\hline \hline
\end{tabular}

Participants' attitude toward active learning was evaluated by a seven item questionnaire on a four-point Likert scale. Table VIII shows participants' attitude toward active learning. The mean was calculated by giving each of the Likert scale points a number value, where strongly disagree $=1$, disagree $=2$, agree $=3$, and strongly agree $=4$. Results indicate that participants who experienced active learning found it delightful and useful.

\section{DISCUSSION}

The purpose of the study was to identify the effects of active learning on pre-service teachers' understanding and skills of curriculum management.

Regarding the first research question "What effects do active learning have on pre-service teachers' understanding of curriculum management?," results of the study show that students who learned actively in a small group increased their understanding in curriculum management week by week $(t$ $(55)=3.03, p<.00)$. Results indicate that if learners learn actively and cooperatively, they could increase understanding on the elements and features of curriculum management. This means that a variety of perspectives, and reflection on each participants' work increase participants' understanding of the features of the curriculum.

With regard to the second research question "What effects do active learning have on pre-service teachers' curriculum management skills?," participants' performance show that learners who learned actively in a small group increased their performance in curriculum management week by week ( $t$ (55) $=6.51, p<.00)$. Results suggest that if students learn actively and cooperatively, they could understand what is important in managing a curriculum. Moreover, results of participants' peer evaluation indicate that participants improved their skills in analyzing a curriculum and organizing a presentation. It is interesting that the mean score of the fourth item: "Has pointed out features of the 'Courses of Studies' which I did not notice." has not increased. This should not mean that participants' skills in curriculum management have not improved but their point of view has become valid.

With regard to the third research question "What effects do active learning have on pre-service teachers' attitude toward active learning? ," results of the questionnaire survey revealed that participants recognized that via active learning, they could learn how to learn, they were delightful learning in a group, they could focus on studying, they could deepen their understanding of the topic, they could understand the importance of the group members, and they could understand the importance of individual learning. However, 25.00 percent of the participants mentioned that they do not agree that they could develop confidence by learning cooperatively. It is expected to explore strategies to increase students' confidence in learning cooperatively to enhance the quality of active learning.

\section{CONCLUSIONS}

Results of the current study suggest that active learning enhances learners' knowledge and understanding of curriculum management, and promotes learners' skills to manage a curriculum. Results indicate that learning in a small group with a variety of perspectives provide valid view of what is important in the curriculum they are managing. Results also suggest that active learning has positive effects on learners' attitude toward active learning. Via active 
learning, participants were delightful and they could focus on studying. They could also understand the importance of learning cooperatively and learning individually.

As the participants of the current study were Japanese pre-service teachers who were taking teacher education courses in university, it is recommended to use other samples from other ages, nationality, and prior teaching experience for future generalization. Especially, it is meaningful to investigate the effects of active learning on in-service teachers' understanding and skills of curriculum management.

Given the findings of the study, it is necessary for pre-service teachers in Japan-who are required to promote active learning-to experience, understand, and design curricula and lessons for active learning. Therefore, it is important to introduce pre-service teachers to active learning methods such as the jigsaw method that require students' activity and their engagement in the learning process.

In addition, findings of this study are expected to contribute to suggest teacher educators how to promote pre-service teachers' confidence or self-efficacy in active learning. It is also expected to facilitate pre-service teachers' understanding and skills to facilitate students' self-efficacy in active learning, and consequently lead to enhance the quality of active learning in elementary and secondary schools.

\section{ACKNOWLEDGMENT}

This work was supported by JSPS KAKENHI: Grant-in-Aid for Scientific Research (C), Grant Number 25350360

\section{REFERENCES}

[1] Z. Ezziane, "Information technology literacy: Implications on teaching and learning," Educational Technology \& Society, vol. 10, no. 3, pp. 175-191, 2007.

[2] Y. Punie, D. Zinnbauer, and M. Cabrera, A Review of the Impact of ICT on Learning, European Commission, Joint Research Centre, Institute for Prospective Technological Studies, 2008.

[3] Organization for Economic Co-operation and Development. (May 2005). The Definition and Selection of Key Competencies: Executive Summary. [Online]. http://www.oecd.org/pisa/35070367.pdf

[4] Central Council for Education, Improving "Courses of Study" of Kindergartens, Elementary Schools, Lower and Upper Secondary Schools, and Schools for Special Needs Education: Report, Tokyo: Ministry of Education, Culture, Sports, Science and Technology, 2008.

[5] C. C. Bonwell and J. A. Eison, Active Learning: Creating Excitement in the Classroom (ASHE-ERIC Higher Education Rep. NO. 1), Washington D: George Washington University, School of Education and Human Development, 1991.

[6] M. Prince, "Does active learning work? A review of the research," Journal of Engineering Education, vol. 93, no. 3, pp. 223-231, 2004.

[7] L. Springer, M. Stanne, and S. Donovan, "Effects of small-group learning on undergraduates in science, mathematics, engineering and technology: A meta-analysis," Research Monograph, no. 11, 1997.

[8] D. Johnson, R. Johnson, and K. Smith, Active Learning: Cooperation in the College Classroom, 2nd ed. Edina, MN: Interaction Book Co. 1998a.

[9] D. Johnson, R. Johnson, and K. Smith, "Cooperative learning returns to college: What evidence is there that it works?" Change, vol. 30, no. 4, pp. 26-35, 1998 b.

[10] R. Hake, "Interactive-engagement vs. traditional methods: A six-thousand-student survey of mechanics test data for introductory physics courses," American Journal of Physics, vol. 66, no. 1, p. 64 , 1998.

[11] E. Redish, J. Saul, and R. Steinberg, "On the effectiveness of active-engagement microcomputer-based laboratories," American Journal of Physics, vol. 65, no. 1, p. 45, 1997.
[12] P. Laws, D. Sokoloff, and R. Thornton. (July 1999). Promoting active learning using the results of physics education research. UniServe Science News. [Online]. 13. Available: http://science.uniserve.edu.au/newsletter/vol13/sokoloff.html

[13] C. A. Benware and E. L. Deci, "Quality of learning with and active versus passive motivational set," American Educational Research Journal, vol. 21, no. 4, pp. 755-795, 1984.

[14] Z. E. Dadach, "Quantifying the effects of an active learning strategy on the motivation of students," International Journal of Engineering Education, vol. 29, no. 4, pp. 1-10, 2013

[15] L. Soltanzadeh et al., "The effect of active learning on academic achievement motivation in high schools students," Archive of Applied Science Research, vol. 5, no. 6, pp. 127-131, 2013.

[16] J. D. H. Gaffney, A. L. Housley Gaffney, E. L. Usher, and N. A Mamaril, "How an active-learning class influences physics self-efficacy in pre-service teachers," in Proc. the 2012 Physics Education Research Conference, 2012, pp. 134-137.

[17] S. S. Boswell, "Undergraduates' perceived knowledge, self-efficacy, and interest in social science research," The Journal of Effective Teaching, vol. 13, no. 2, pp. 48-57, 2013.

[18] G. Trujillo and K. D. Tanner, "Considering the role of affect in learning: Monitoring students' self-efficacy, sense of belonging, and science identity," Life Sciences Education, vol. 13, pp. 6-15, 2014.

[19] R. R. Wilke, "The effect of active learning on student characteristics in a human physiology course for nonmajors," Advances in Physiology Education, vol. 27, no. 4, pp. 207-223, 2003.

[20] O. Akınoğlu and R. Ö. Tandoğan, "The effects of problem-based active learning in science education on students' academic achievement, attitude and concept learning," Eurasia Journal of Mathematics, Science, \& Technology Education, vol. 3, no. 1, pp. 71-81, 2007.

[21] Ministry of Education, Science and Culture, Japan's Modern Educational System, Tokyo: Ministry of Education, Culture, Sports, Science and Technology, ch. 6, 1980.

[22] Central Council for Education, The Model for Japanese Education in the Perspective of the Twenty-First Century, Tokyo: Central Council for Education, part 2, ch. 1, 1996.

[23] Ministry of Education, Culture, Sports, Science and Technology, Japanese Government Policies in Education, Science, Sports and Culture 1996, Tokyo: Ministry of Education, Culture, Sports, Science and Technology, ch. 3, 1996.

[24] Ministry of Education, Culture, Sports, Science and Technology. (2010). Zest for Living: Pamphlet for Parents. [Online]. Available: http://www.mext.go.jp/a_menu/shotou/new-cs/pamphlet/_icsFiles/af ieldfile/2011/07/26/1234786_1.pdf

[25] Ministry of Education, Culture, Sports, Science and Technology, FY 2005 White Paper on Education, Culture, Sports, Science and Technology: Efforts in Education Rebuilding/Realization of a Nation Based on Culture and the Arts, Tokyo: Ministry of Education, Culture, Sports, Science and Technology, ch. 1, pp. 3-30, 2006.

[26] Ministry of Education, Culture, Sports, Science and Technology. (December 2006). About the New Basic Act on Education. [Online] Available: http://www.mext.go.jp/b_menu/kihon/houan.htm

[27] Ministry of Education, Culture, Sports, Science and Technology, The Development of Education in Japan 2005-2008, Tokyo: Ministry of Education, Culture, Sports, Science and Technology, part II, ch. 1, pp. 60-64, 2008

[28] Ministry of Education, Culture, Sports, Science and Technology. (March 2008). Courses of Study. [Online]. Available: http://www.mext.go.jp/a_menu/shotou/new-cs/youryou/syo/

[29] Prime Minister of Japan and His Cabinet, New Growth Strategy, Tokyo: Prime Minister of Japan and His Cabinet, 2010.

[30] Ministry of Education, Culture, Sports, Science and Technology, The Vision for ICT in Education - Toward the Creation of a Learning System and Schools Suitable for the 21st Century, Tokyo: Ministry of Education, Culture, Sports, Science and Technology, 2011.

[31] Central Council for Education, Curriculum Standards for Elementary and Secondary Education: Inquiry, Tokyo: Ministry of Education, Culture, Sports, Science and Technology, 2014.

[32] Central Council for Education, Tactics to Improve Curricula and Instruction for Elementary and Secondary Education: Report, Tokyo: Ministry of Education, Culture, Sports, Science and Technology, 2003

[33] E. Aronson. (January 7, 2014). Jigsaw Classroom. [Online] Available: http://www.jigsaw.org/

[34] E. Aronson, "Training teachers to use jigsaw learning: A manual for teachers," in Cooperation in Education, S. Sharan, P. Hare, C. D. Webb, and R. Hertz-Lazarowitz, Eds. Provo, UT: Brigham Young University Press, 1979. 
[35] D. W. Johnson, R. T. Johnson, and E. Holubec, Circles of Learning: Cooperation in the Classroom, 3rd ed. Edina, MN: Interaction, 1990.

[36] M. W. Goodwin, "Cooperative learning and social skills: What skills to teach and how to teach them," Intervention in School and Clinic, vol. 35, no. 1, pp. 29-33, 1999.

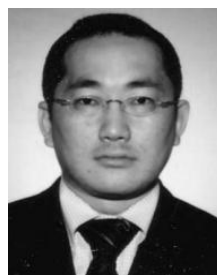

Hiroki Yoshida was born in Nara, Japan in 1973. He received the MEd degree in educational methodology (audio-visual education) from International Christian University, Tokyo, Japan in 2001.

$\mathrm{He}$ worked at the Japan Audio Visual Education Association (JAVEA) from April 2000 to March 2002.

He has been teaching pre-service teachers in Tokoha University in Shizuoka, Japan since April, 2002. He is currently a professor at the Faculty of Education, Tokoha University. His research interests include teacher education, online learning, cooperative learning, and hypermedia education. 